\title{
Political Circumstances in Albania from 1920 to 1924
}

\author{
Skender Lutfiu, PhD Cand \\ Institute of History, Prishtinë
}

\begin{abstract}
The events that marked the period 1920-1924 are undoubtedly those of an interior character such as the Congress of Lushnja and the Vlora War (1920), the parliamentary elections (1921 and 1923), the June uprising (1924), etc. while the external ones are undisputed the recognition of Albania and its borders at the London Conference (9 December 1921) and its admission to the League of Nations (1921). The democratic system imposed by the Congress of Lushnja, proved to be ineffective. That is, because it didn't bring political and economic stability in the country, but on the contrary caused instability in large proportions, all because of the coup d'etat and the numerous uprisings that characterized the period 1920-1922. When the armed political struggle in Albania intensified, nationalist and moderate concepts were created in the Albanian politics. During this period, the Albanian political scene was divided into several political views through North-South contradictions, Muslim-Christian, Zogu-Noli, Conservative-Liberal, and so on. This diversity of religious, regional, political and conceptual character led to political rivalry within the Albanian leadership in Albania over the 19201924 period, in the name of democratic principles, even with non-democratic means. By thus creating not only a serious political climate, but also an attempt for radical changes in the country's government, such as the June Uprising of 1924.
\end{abstract}

Keywords: Albania, political circumstances, the Congress of Lushnja, June uprising, political parties, Zogu, Noli etc.

\section{Introduction}

\section{Political circumstances in Albania from 1920 to 1924}

After the First World War, Albania was not only crushed in all areas, but it also lost its subjectivity as a result of the circumstances it had undergone during the war years. (Georges Castellan, 1997, 450). The government of Durres, which was created immediately after the end of the war and was under Italian influence, did not duly represent the interests of the Albanian nation, so the well-known personalities sought to hold a national congress. Preparations for the congressional meeting showed that the Government of Durres was increasingly narrowing its internal support. Moreover, the Albanian officers and soldiers abandoned the government, because they were not only dissatisfied with her work, and wanted to change the overall situation in Albania. (Historia e Popullit Shqiptar III, 2007, 144). Driven by the fear of further fragmentation of Albanian territories in the agreements that could be reached at the Peace Conference, the Albanian patriots organized a national congress that was held in Lushnja from 21 to 31 January 1920 (Hysen Selmani, 2008, 108), outside the Italian occupation zone (Tahir Abdyli, 2003, 226-227). Important decisions for the history of the Albanian state were made in the Lushnja Congress. What is worth mentioning is that in its program, along with the call for participation of delegates in the first paragraph is stated, that:" The purpose of the general meeting is to secure the Albanian union" (AQSH, F, Kongresi i Lushnjës, D, 1). In general, this congress reaffirmed Albania's independence, including the commitment to preserve its territorial integrity, and the non-recognition of all treaties and secret agreements that were at contrary to the interests of the Albanian state. (Afrim Krasniqi, 2006, 45). The main decisions taken at this assembly were: the fall of the Durrës government, headed by Turhan Pasha Përmeti, which was under the Italian protectorate; the election of the Supreme Council (Council of Regency) to represent the independence of the Albanian state, until the king ascends the throne of Albania, where they were assigned: Aqif Pasha Elbasani (Bektashi), Abdi Bey Toptani (Suni Muslim), Bishop L. Bumçi (Catholic) and Doctor Mihal Turtulli (Orthodox), (Tajar Zavalani, 1998, 259). Also, a decision was made for the formation of 
a National Council ${ }^{*}$ (Parliament), consisting of 37 councilors who had parliamentary competences. The 1920 National Council held two parliamentary sessions ${ }^{* *}$. At the Congress of Lushnja, the following decisions were also taken: submission of a resolution to the Peace Conference in Paris, through which they protested the partition plan of the Albania territory and the election of a three-member delegation to represent the Albanian problems at the Paris Peace Conference (Edwin Jacques, 1998, 406). Then creation of a national army (Miranda Vickers, 2008, 152), repudiation of the 1915 London Agreement (Sejfi Vllamasi, 2000, 186), determining the form of the regime, confirming the continuation of the form of constitutional monarchy, which had begun since the establishment of the Albanian state in 1912/1913 (Afrim Krasniqi, 2006, 45 ) and the announcement of Tirana as the capital city instead of Durres. (Peter Bartl, 1999, 179).

Despite this, a temporary government was formed in Lushnja under the chairmanship of Sylejman Delvina (Fjalori Enciklopedik Shqiptar 3, 2009, 2157-2159; Robert C. Austin, 2011, 349-351; llir Ushtelica, 1997, 35). Both the High Council and the National Council, who emerged from this congress, guaranteed that they would strive for the "protection of a free and independent Albania", but the maturity of Albanian diplomats of the time was constantly sought. In addition to the Lushnja Government, the continuously effort for the national issue by the Kosovo National Defense Committee*, which in its meeting held on 30 August 1920, decided to accept the charter program of this committee, which consisted of three articles.

The Lushnja government, which was set up on 11 February in Tirana, was welcomed by the people. On the other hand, the provisional government of Durres, given the circumstances created, on 20 February 1920, handed over the offices and archives to the Government of Tirana (Hysen Selmani, 2008, 118). Another important issue for the Government of Tirana, after that with the French troops for handing over the city of Shkodra, was also the war and liberation of Vlora from the Italian forces (Historia e Popullit Shqiptar III, 150-167; Hysen Selmani, 2008, 124-129). This issue was resolved on 2 August 1920 , when the protocol between the two governments was signed for the withdrawal of the Italians from Vlora, who left on 3 September (Miranda Vickers, 2008, 154).

After this success the Tirana government managed to exert its influence on the whole territory of the Albanian state. However, what was the internal situation of the Albanian state in this period of restoring its subjectivity as a state? Albania had enormous difficulties in the internal affairs in all areas. The situation was exacerbated by external influences and regional differences. Thus, the Austrian influence was observed in the north, the Italian on the coast, and the Greek one in the south. There were no political traditions at all, due to the long dominance of the Ottoman Empire in the Albanian territories. While in the north tribal influence played a key role, this role played feudal ties in central Albania. Somewhat better was the south, where we can speak of a small class of merchants and sailors, but their impact at the country level were irrelevant (Georges, Castellan, 1997, 452).

With all the difficulties, that Albania had to deal with (internal and external), there were great successes during 1920, such as the Congress of Lushnja, the Vlora War, the acceptance of Albania and its recognition in the League of Nations. But despite the above-mentioned successes, on 24 November 1920, 18 self-proclaimed opposition members that constituted half of the National Council, resigned, demanding new elections (Afrim Krasniqi, 2006, 47). That is why the Tirana Government set itself the task of organizing elections and legitimizing a parliament that expressed the will of the people, with a decision taken on 14 December 1920.

\footnotetext{
- The National Council or Parliament, called from the beginning the "Senate", had a short life span (held only two sessions). The role of the first Albanian Parliament was enormous. This is due to the fact that the Albanians expressed the political will to take their fate in their hands, then established the Albanian parliamentarism and took over all the responsibilities of the historic decisions of the Lushnja Congress. The challenges faced by the National Council were the reaffirmation of the independence, the confirmation of the country's internal and external sovereignty, the form of governance in Albania, and so on. More details: Kaliopi Naska, (2000), Këshilli Kombëtar 1920 (Parlamenti i parë shqiptar), Drejtoria e Përgjithshme e Arkivave, Tiranë, etj.

${ }^{*}$ From March 27, 1920, when this parliament was opened until May 27, 43 meetings were held (first session) and from 23 September to 15 November 1920, 27 meetings were held (second session).

- The "National Defense of Kosovo" Committee was formed in Shkodra in 1918, with President Hoxha Kadri Pristina. This committee was a political organization with democratic principles and the main body of patriotic movement of the Albanian people in Kosovo in particular and nationwide in general. Its main aims were to maintain the independence of the Albanian state, its democratization, the liberation of Kosovo and its unification with Albania. See more: Zamir Shtylla, (1986), "Rreth krijimit dhe veprimtarisë së Komitetit Mbrojtja Kombëtare e Kosovës në vitet 1918-1920", Studime Historike, nr.3, Instituti i Historisë, Tiranë; Lush Culaj, (1997), "Komiteti Mbrojtja Kombëtare e Kosovës 1918 - 1924", Instituti Albanologjik i Prishtinës, Prishtinë, etc.
} 
As the external problems were overcome, the internal problems that were mainly connected with the movement for democratic change, where the war in the Parliament and the parliamentary elections played an important role, which began in the spring of 1921, came into the forefront. Bearing in mind that this were the first constitutional elections, were for the first time political groups were involved that claimed to be political parties, it was understandable that the final result would be delayed. The entire process lasted from the end of January 1921 to April, respectively until May, when they were completed in Shkodra (Peter Bartl, 1999, 241-243).

Due to the severe political situation on 14 November 1920, after the meeting of the Council of Ministers, the chairman of the government Sylejman Delvina demanded resignation, as a result of the constant pressure being made both from inside the government and by the National Council (Kaliopi Naska, 2000, 110) and by the High Council, institutions which repeatedly complained, because according to them the government acted without the prior approval of these bodies (Afrim Krasniqi, 2006, 48). Whereas, according to the scholars Puto and Fischer, Prime Minister Delvina had a continuous clash with Zogu, who held the post of interior ministries, but aimed at the post of the prime minister. Under these circumstances, the loss of influence of his government, Delvina resigned, thus becoming the first Albanian government to leave, not only in a peaceful but extremely democratic way, because it lost the support of a majority in the National Council. Moreover, Prime Minister Delvina himself stated: "since we do not have a majority in the Parliament on which the government is based" (Bisedimet e Këshillit Kombëtar, 1920, 175).

Thus, after the significant restriction of activity and the resignation of the government of Sulejman Delvina (Kaliopi Naska, $2000,111-112$ ), efforts were made by all for the election of a new, neutral government, and for the election of a unifying prime minister for all parties (Sejfi Vllamasi, 2000, 232). Moreover, the National Council, in its 70th meeting, held talks on the impeachment of the government of lljaz Vrioni, who was appointed on 19 November 1920, as Prime Minister by the State Council, and was a representative of the conservative power with the support of the influential beys, who were landowners. However, this government was temporary, a fact that Prime Minister Vrioni emphasized, when he said that "his government would lead the Albanian state until a new government is created by the new parliament, which would be the result of new elections" (Kaliopi Naska, 2000,113). Moreover, the drafting of the bill on the new elections on 5 December 1920 and the decision to start the elections on December 21 are considered the main decisions of this government (Kaliopi Naska, 2000, 113). According to this law, elections would be held, not for the Constitutional Assembly, as required by the Lushnja Statute, but for deputies in the National Council. (Historia e Popullit Shqiptar III, 2007, 178). This was the reason why the state of internal affairs was worsening and led to the clash of the political forces (Arben Puto, 2009, 315).

The political life in Albania during 1920-1924 was developed thanks to the creation of the first Albanian political parties, which played an important role in the further political processes. Thus, after these elections, specifically on October $10^{*}$ the People's Party "was created from the "National Wing". This was the largest party, which brought together most famous personalities like Fan Nolin, who was also the first party leader (Nasho Jorgaqi, 2005; Estela Palnikaj \& Dritan Palnikaj, 2016, 50), then Luigj Gurakuqi, Eshref Frashëri, Stavri Vinjaun (Afrim Krasniqi, 2006, 50), etc. The proponents of this party were basically liberal and Western-oriented. Its program consisted of 20 points. On 21 November 1920, the Progressive Party or the Democratic Party was formed. This was the party of the beys, which mainly represented the interests of Central Albania, where the landowners held the power. It was led by Shefqet Vërlaci, while it also included members of the Kosovo National Protection Committee such as Hoxha Kadri Prishtina, Hasan Prishtina and Bajram Curri". The "Progressive Party" program aimed at Albania's national unity, independence and development (Kaliopi Naska, 2000, 106).

The formation of the above-mentioned political parties, which were created during the election campaign, lacked political and organizational experience. The historian Bernd Fischer, describing the political culture in Albania, says that "the power of a leader did not depend on the number of votes but the number of rifles". The Albanian position and opposition were almost equal with the number of MPs, a fact that encouraged more struggle for power. Therefore, this was the reason why there was a permanent and fierce struggle between them, causing continual government crises, until the formation of a

\footnotetext{
* There are different opinions about the date of the founding of the People's Party. In the Historia e Popullit Shqiptar III..., it is said that the "People's Party" was formed on 10 October 1920. We find this date in Afrim Krasniqi, mentioned publication, p. 49. Researcher Miranda Vickers should be wrong when she writes that this party was founded on 24 April.

** This political subject was also known as the Progressive Party. See more: Miranda Vickers, mentioned publication, p. 163. It is worth pointing out that the members of this political subject were named Conservatives.

- Hasan Prishtina and Bajram Curri were part of the People's or Democratic Party.
} 
national coalition government in the fall of 1921 (Miranda Vickers, 2008). But it should be borne in mind that the political parties and also the Albanian parliament were born on an unknown terrain and in extremely difficult historical circumstances. If we add to this the lack of democratic experience, the idea of demanding full parliamentary democracy and free political competition is becoming more difficult in a country where it has not yet been liberated from tribal influences and where there were still no clear borders as a result of wars and long occupations (Afrim Krasniqi, 2006, 49).

Along with the three above-mentioned parties, a series of progressive organizations were formed during this period, aimed at oppose the rule of Muslim landowners. Such were the Federation „Atdheu” (engl. Homeland) (Neil Shehu, 1977, 63; Historia e Popullit Shqiptar III, 2007, 202-204), then the society „Bashkimi” (engl. Union) (Statuti i Shoqnis “Bashkimi”, 1924; Muin Çami, 1974; Studime Historike", No. 3, 41; Miranda Vickers, 2008, 155; Historia e Popullit Shqiptar III, 2007, 204), "Ora e Maleve" (engl. Mountain Time)", "Krahu Kombëtar" (engl. National Wing) (Sejfi Vllamasi, 2000, 268-269), etc. The above mentioned organizations have played a significant role in the development of the political life in Albania in the years 1920-1924.

One of the most difficult times of political life, of the time frame of 1921-1924 is undoubtedly the end of 1921, known as the December crisis. To get out of this difficult situation, efforts were made by the Albanian political class to join together, because they saw the danger from neighboring countries. Thus, in October 1921, a broad political coalition was created between the position and the opposition, known as the "Holy Union", which then resulted in the collapse of the government of Prime Minister Vrioni and the election of a new government, with Prime Minister Pandeli Evangjeli. His election was accompanied by disappointment and criticism, which led to the fall of this coalition government three weeks later. (Afrim Krasniqi, 2006, 61).

Thus, on 4 November, the High Council decided to dissolve the Parliament elected in April, due to the Mirdita Uprising*. While the Parliament once again rejected, but later admitted, Prime Minister Pandeli Evangjeli, under the pressure of the uprising, decided to establish two commands, one in the East under Ahmet Zogu's command and one in the West under the command of Bajram Curri. On the other hand, as a counter reaction, Aqif Pasha, demanded the resignation of the prime minister. The dismissal of Prime Minister Evangjel was signed on December 6, 1921 by Aqif Pasha Ebasani and Bishop Bumçi, who were members of the High Council. Although Evangjeli refused stating that he would resign when the Parliament was convened, under constant threats, he was forced to resign. (Albana Mema, 2014, 129). This act created a serious and extremely negative precedent in the process of the rule of law and democratic progress.

After the fall of Evangjeli, the mayor of Tirana, Qazim Koculi, was assigned, for the creation of the new government, who, seven hours later, fearing reactions throughout Albania, resigned. Koculin was replaced by Hasan Prishtina, whom the Supreme Council assigned to form the cabinet. Thus, on 7 December 1921, he formed the new government, which included personalities like Louis Gurakuqi Fan Noli, Bajram Curri, Hoxha Kadri Prishtina, Zija Dibra, Koco Tasi, Kristo Dako and Haki Tefiku, who held the posts of ministers (Skender Drini, 1984, 274; Xheladin Shala, 2014, 127). But on 12 December (Kujtim Nuro \& Nezir Bata, 1982, 120), under the pressure of the citizens, mainly from the south and beys of middle east Albania, who were against the domination of the North, and after a great demonstration in Tirana, Prishtina was forced to resign.

The Government of Prishtina was replaced by Idhomeno Kosturi, whom the two members of the High Council, Aqif Pasha and Bishop Bumçi, charged with the formation of the government from office directors until the parliament meets to form a definitive government. However, neither the government cabinet, headed by Kosturi, could manage to stay long due to the lack of internal and external support. Under these circumstances, he was forced to resign, 12 days after the government's proposal, who was replaced by Xhafer Ypi (Sejfi Vllamasi, 2000, 264).

\footnotetext{
" Ora e Maleve, was founded in Shkodra by a small group of Catholics led by Luigj Gurakuqi. It became the voice of the opposition and the defense of the interests of the northern and the catholic minority of Shkodra.

$\square$ After receiving promises of help from the Yugoslavs, Marka Gjoni returned to Mirdita, propagating against the Vrioni administration. While the Yugoslavs proclaimed from Prizren the so-called Mirdita Republic, he accused the Tirana Government of being a Muslim one, with a tendency of Young Turks that was planning to intervene in the religious freedom of the Mirdita who were Catholics. With this excuse, he was confident by the support of the Yugoslavs who provided funds, military preparations and armaments, and attacked the military troops. However, fortunately, this rebellion was short-lived, because his forces did not cross the figure of two thousand troops, many of whom were less Mirdita, as most were either Serbian or Albanian irregular troops. See more Peter Bartl. Mentioned publication, p. 186.
} 
Xhafer Ypi's government was established two days after Zogu has entered Tirana, where he took command of the gendarmerie and called the National Council (Peter Bartl, 1999, 187; Liman Rushiti, 2016, 214).

In the Government of Xhafer Ypi (December 24, 1921-26, December 1922) (Sejfi Vllamasi, 2000, 267; Joseph Swire, 2005, 303), Zogu did not yet see the moment to seize power, however as interior minister he strengthened his position. In fact, this government which took the confidence of parliament, to avoid giving the impression the government monopolization by the popular party that was in power, three ministerial posts were given to the "independents" (Historia e Popullit Shqiptar III, 2007, 183). To include all religious communities in Albania, Ypi's cabinet chose four representatives, one from each religious confession ${ }^{*}$

As a result of major opposition discontent began in Puka the anti-Zogu uprising of March 1922 (Hysen Selmani, 2008, 141144), where Bajram Curri along with other Kosovar leaders led this uprising against Zogu, which spanned in only three prefectures: in the prefecture of Kosovo, in that of Dibra and Durrës. Within a short time, the insurgents managed to take Durrës, then marching to Tirana (Miranda Vickers, 2008, 170). When the insurgents approached Tirana, most of the government and the National Council, which on February 25, 1922 interrupted their work, and the High Council fled hastily to Elbasan, leaving the protection of the capital to Zogu and some of its supporters. (Miranda Vickers, 2008, 170). When the forces of Elez Isufi entered Tirana on 8 March $1922^{* *}$, and took over a part of the capital, Zogu gathered the notables of Tirana, and on the same day the Minister of Great Britain has arrived from Durres in Tirana, Mr. Hersy Eyres, who started the negotiations with both sides in the house of Ali Shefqet in Tirana. (Kastriot Dervishi, 2006, 161). It was also the intervention of Eyres, who upon Zogu's request, managed to convince the commander of the uprising, Elez Isufin to surrender (Joseph Swire, 2005, 313; Arben Puto, 2009, 325).

The opposition justified the uprising as an action motivated by the urgent need of the Constitutional Assembly, unlike the position, which stated that "to set the foundations of the political life of a country you cannot do the assembly under rifle under fist influence of several individuals" (Albana Mema, 2014, 142).

The same attitude with the position was also made by international organizations, who openly expressed their position for the convening of the Constitutional Assembly, but after the final determination of the borders.

Following the failure of the March 1922 movement, Xhafer Ypit's second government was formed, which consisted of the same ministers, with the exception of Pandeli Evangjelit, who was appointed Minister of Foreign Affairs instead of Fan Noli, who had resigned a week before Elez Isufi's forces entered Tirana (Sejfi Vllamasi, 2000, 278).

Although he had received the vote of confidence, in September Xhafer Ypi resigned as Foreign Minister, who was replaced by Pandeli Evangjeli, while on 2 December he also released the post of Prime Minister, who was replaced by Ahmet Zogu (Joseph Swire, 2005, 320).

The government of Zogu*, which was formed on 2 December 1922, retaliated against patriots and villagers who had been part of the uprising. Apart from the murder in Peshkopi of Ramiz Daci, who was the organizer of this uprising, another 70 people were killed, its chief executives sentenced to death in absentia, 300 others were detained, hundreds of officers degraded and burned hundreds of houses (Mediha Jasa, 1958, 23; Peter Bartl. 1999, 188). Whereas, Bajram Curri and Hasan Prishtina, after the failure, were forced to flee to the highlands of the prefecture of Kosovo (Kukes) and Shkodra (Sejfi Vllamasi, 2000, 272-279), who were constantly pursued by the government.

Political circumstances in Albania from March 1922 until the 1923 elections were severe, as the order ended, leaving the country to the most complex events as a result of campaign development by parties, leaders and groups, representing different interests and views (Seji Vllamasi, 2000, 333).

In the Albanian parliament, the question of the establishment of the monarchist or republican regime was treated very much. Both political groups were more concerned with preserving the existing situation, which means they were about

\footnotetext{
¿Omer Vrioni (Bektashi Muslim), Sotir Peci (Orthodox), Ndoc Pistuli (Catholic), Refik Toptani (Sunni Muslim).

* On 8 March 1922, a large rebel force, led by Cen Elez of Dibra, appeared in Fushë-Krujë, which then progressed to the outskirts of Tirana.

In Zogu's cabinet, there were no major changes from the pre-cabinet. The Minister of Foreign Affairs became Pandeli Evangjeli, while the post of Minister of Internal Affairs was kept by Zogu himself, which was later taken by Sejfi Vllamasi.
} 
holding the Supreme Council, but attempting to expand its powers (Historia e Popullit Shqiptar III, 2007, 214). We can say that the constitutional assembly elections preceded this division of the political spectrum that reflected in the lack of consensus about establishing a form of governance.

By the summer of 1923, the Albanian political scene is deepening furthermore, so that the differences grew more and more between the landowners and those without land, the northern and southern, the liberals and the conservatives, the Muslims and the Christians (Orthodox and Catholics) and so on. It should be noted that one of the main causes of dissatisfaction among Christians and Muslims was the unequal treatment of Christians by the Muslim majority (Miranda Vickers, 2008, 173).

While parliament, after finishing the budget vote, ceased its activity on 18 June 1923., the parliament's dissolution sparked hope among the Albanian opposition to overthrow the government. The outcome of the elections, which precisely reflected the political climate in Albania, also highlighted regional divisions, because opposition forces mainly won in the south and north of the country. The opposition did not accept the election results, and even she was convinced that the indirect vote had won, because in the second round the results had that end because the government used scams, strength, and all they could to prevent the victory of the wing of Noli (Robert C. Austin, 2011, 97-98). These elections complicated even more the political situation with the fact that with their results the allocation of seats in parliament did not give a clear majority, while the government won only 40 of the 95 seats in the Constitutional Assembly. This led Zogu's cabinet to resign after two weeks to be replaced by Shefqet Vërlaci. Zogu further continued his great influence on the government, since neither Vërlaci was acceptable to the opposition.

\section{Causes of internal chaos in Albania on the eve of the June Uprising}

The parliamentary elections that took place in November/December 1923, which ended on December 27, brought the victory of the political groups that supported Zogu and the policy he was pursuing. On the other hand, the opposition openly rejected the election results, so the country's political situation deteriorated more and more, as a result of the narrow gap between the two sides' votes. Thus, the newly elected Assembly came together on 21 January 1924, at whose head Petro Goga was elected. She made an attempt to pass on important issues, as the final decision on the form of government, the allocation of capital $^{*}$ and finally passed in the elections for the new parliament. However, these issues were not chosen, because the opposition was not interested in pushing these processes forward (Robert C. Austin, 2011, 100-101). This situation is due to the confrontation between the deputies, some of whom were liberal, while others were conservative (Emine Arifi-Bakalli, 2015, 306). The contradictions between them deepend so far, that they were leading the country to anarchy.

It must be said that in early 1924, Albania experienced a deep political and economic crisis. The famine that engulfed the north of the country (economic aspect) and the repetition of the demand by the Serbo-Croat-Slovene Kingdom for St. Naum and Vermosh (political aspect), affected the disturbance of the Albanian public and the holding of many protest rallies (Emine Arifi-Bakalli, 2015, 307).

The assassination attempt against Zogu on 24 Feburary 1924** (Historia e Popullit Shqiptar III, 2007, 218) was a signal, that further thwarted the deep political crisis that ruled in Albania. The next day, a group of about 29 opposition members, lead by Fan Noli, Sylejman Delvina, Luigj Gurakuqi, Avni Rrustemi and others, addressed a statement to the High Council, which stated that: "The continuation of the government in power, would mean the total destruction and internal and external confusion, that could be fatal for life of our Fatherland." Furthermore, this document proposed the formation of a government, in which, after the fall of the ministers, a government cabinet and a prime minister should be elected, who would enjoy the trust of all political groups (Emine Arifi-Bakalli, 2015, 307).

Zogu resigned on the same day from his position as prime minister, working against the opposition from an unofficial position, because he asked the regency to appoint Shefqet Vërlaci to form the new government Zogu resigned on the same day from his position as prime minister, working against the opposition from an unofficial position, because he asked the regency to appoint Shefqet Vërlaci to form the new government (Joseph Swire, 2005, 336). The cabinet of the government

\footnotetext{
For the setting of the capital, there have had clashes mainly between the organizations Ora e Maleve, which in her program had the appointment of Shkodra for the capital, and the newspaper Politika e Vlorës, which was to make Vlora the capital.

** The assassination of Zogu took place on 23 February 1924 by 17-year-old Beqir Volteri, on the stairs of the Albanian Parliament.
} 
led by Vërlaci, who took office on March $3^{*}$, sparked even more resistance to the opposition, which they as an ally of Zogu and who only represented the interests of the landowners (Robert C. Austin, 2011, 105).

For this reason, about 30 members of the opposition, denounced the cabinet of Vërlaci as Zogu's gadget, whereas the member of Vatra, Faik Konica resigned from his position in parliament. From March 1924 on, the government had three strong opponents: progressive forces lead by Noli, the Kosovo Committee and the Albanian Army (Robert C. Austin, 2011, 105-107).

Under this circumstances, the hope for cooperation between the position and opposition faded even more, while the economic and social situation in Albania worsened day by day. The events that preceded the June Uprising, are without a doubt the killing of two American tourists, G.B. de Long and R.L. Coleman, on 6 April 1924, who were travelling from Tirana to Shkodra (Peter Bartl, 1999, 190). Their killing supported the accusation of the opposition and the government that further affected the heavy political climate in the country. But the assassination that made the biggest rage in Albania, resulting in accusations' and counter-claims between the opposition and position, was without any doubt the deadly wounding of Avni Rrustemi on 20 April 1924, one of the protagonists of the opposition and the representing member of the organization "Bashkimi". The event was politicized and used by the Albanian opposition, accusing Zogu, for being involved in this assassination. However, the assassination of the parliament member Avni Rrustemi*, was a clear political crime, that had not only an influence on the cutting of bridges of communication between the government and the opposition, but was also the starting point of the spring events of 1924, an event that led to the uprising of June (Arben Puto, 2009, 348). The river of anti-governmental accusations didn't have an ending in sight before, during and after the burial of Avni Rrustemi (Historia e Popullit Shqiptar III, 2007, 222). Thus, on 30 April, 26 parliament members of the Democratic Party held a meeting in the Municipality of Vlora, where they demanded that the Constitutional Assembly should convene in Vlora and not in Tirana. At the same time, 49 parliamentary members continued they work in Tirana. On the other hand, the opposition from Vlora demanded the resignation of the Vërlaci government, because as expressed by the government, it was impossible to guarantee the lived of the Albanian citizens and that of foreigners. They also accused the government for the country's miserable economic situation etc. (Miranda Vickers, 2008, 177).

Whereas, on 28 April Noli denounced the government was "anti-nationalist", and that the people could expect nothing from the government or the Assembly. The oppositional newspaper Politika, wrote during this period: "Zogu was working against the national interests, because he was a Serbian tool and he, like Esad Pasha, was determined to make Albania a Serbian province" (Politika, 3 maj 1924).

On $30 \mathrm{May}^{*}$ the cabinet of Vërlaci resigned, to be replaced with that of Ilias Vrioni, who became prime minister and foreign minister. After the high officials of Vrioni administration fled to Italy, the military units joined the opposition. On the other side, in Vlora was created the Temporary Administrative Commission (Historia e Popullit Shqiptar III, 2007, 224), that was a kind of government, but resigned on 15 June, as a result of financial collapse and other factors. Also, the foreign diplomats who were accredited in Tirana, representing the interests of the countries they came from, didn't stay out of these developments. It's important to mention the representatives of the powers, that had political and economic interests in Albania, who incited the governmental forces for resistance. The most engaged in this direction was the representative of Great Britain, H. Aires.

\section{The democratic government of Noli}

The government of Noli, which was created on 16 June 1924 (Miranda Vickers, 2008, 178; Joseph Swire, 2005, 343) consisted of the most famous political personalities of the time, who had a progressive orientation and claimed the democratization of Albania (Emine Arifi-Bakalli, 1982, 239; Robert C. Austin, 2011, 135). Without a doubt, the main problem that conveyed Noli continuously was his legitimacy as prime minister*. However, he announced three days after the formation of his government cabinet, on 19 June, a 20-point reform program (AQSH, F. Fan Noli F.14, D.89). The

\footnotetext{
According to researcher Joseph Swire, Vërlaci's government took office by gaining a strong vote of confidence on March the $5^{\text {th }}$. - Vërlaci's government resigned according to researcher Peter Bartl on 27 May 1924, according to Joseph Swire, 1 June, and according to Edward Jacques, this government left on 15 February.

** It was in violation of the Lushnja Statute. Noli stated that the Regulatory Council had authorized him to form a new government, but he did not legitimize it because in Albania there was only one member of this council (Sotir Peci), and under Article 49, this council could not function, without being at least three of its four members.
} 
government of Noli had an extremely difficult beginning, because of the fact that they came to power the through uprising and because Zogu's preliminary governments had robbed the public finances, had rooted corruption and as a result budget deficit were created. Other problems that followed this government was also the ruling class, which continued to be powerful, then the neighboring states that showed great reservations and without a doubt the lack of support of the Great Powers, that became the main problem and had consequently a fatal outcome for the Noli government and its durability (Robert C. Austin, 2011, 131).

Since the international recognition was very important, he left Albania for two months (September and October), went to Geneva, a visit that did cause him much internal problems, because his government created many fractions, who saw their narrow interests. Such were the Union, the National Democrats, the Radical Democratic Party and others (Robert C. Austin, 2011, 162-165). Thus, the struggle between these parties grew increasingly harder. As a result, Albania was divided into areas of influence, where each minister had his influence in a specific prefecture* (Seji Vllamasi, 2000, 375). The army began also to show her dissatisfaction, due to the cutback in the budget, and because of the fear that the Noli government will not be able to defend the country's independence (Robert C. Austin, 2011, 165). When Noli returned to Albania, forced by the disfavoring circumstances that were created in his absence, makes a very important decision. Thus, on November 13, he accepted to hold new elections that should be held from 20 December 1924 until 20 January 1925 (Robert C. Austin, 2011, 167).

Noli legally couldn't postpone the elections any further, because the function on the High Council ended on November 23, and the election of the new High Council had to be done by the parliament, therefore Noli was forced to sign the decree for the new parliamentary elections (Emine Arifi-Bakalli, 1982, 251).

Noli's government has lost its authority among the people, and the people have lost their confidence that it could bring out the country from the general crisis. There are at least three external and internal factors that accelerated the collapse of Noli's government: 1. Lack of unity within the Albanian opposition; 2 . The international non-recognition of his government and 3. The lack of government legalization by the Assembly or through elections. But, as researcher Robert C. Austin says, is "the failure to provide outside support, a poorly equipped army and a relatively uninterested population forced Noli to leave Tirana on December 23" (Robert C. Austin, 2011, 321). While Sejfi Vllamasi, in the reasons of his fall, mentions also Noli's agreement with the Soviet ambassador in Rome, for diplomatic relations between the two governments, Noli's speech at the League of Nations in November 1924 and the kerosene that was not given in time or in the time of this government, to the British Society.

After six months of Noli's government, Zogu returned to Albania (24 December 1924), who was in Belgrade at that time. There were many reasons that favored Zogu's return, such as the support of the Great Powers like Great Britain and Italy (Esilda Luku, 2015, 158-176) and neighboring states like Yugoslavia, which helped more than anyone, and Greece. Upon returning to Tirana, Zogu immediately assumed supreme power as dictator and commander-in-chief while the country remained in state of emergency. On the other hand, Noli, his government and about 350 people, moved to Vlora, from where they left for Italy and Greece.

\section{Conclusion}

The political circumstances in Albania in the period of 1920-1924 are extremely complex because it is the most dynamic period of events that have played a decisive role not only in political and economic processes. Thus, among the most significant events that took place in Albania in the above mentioned period were unquestionably those of an interior character such as the Congress of Lushnja and the Vlora War (1920), the parliamentary elections (1921-1923), the June Uprising (1924), while external ones are undeniably the recognition of Albania and its borders at the London Conference (9 December 1921) and its membership to the League of Nations (1921). All of these events were undoubtedly accompanied by a series of controversies within the Albanian leadership, a fact that has produced destabilization and stagnation.

\footnotetext{
- In the prefecture of Korça, (Noli), of Gjirokastra (Koço Tasi and Stavro Vinjau), of Vlora and Berat (Qazim Koculit), of Central Albania (Mustafa Kruja), of Kosovo, with the center in Kukës (Bajram Curri) and in the prefecture of Shkodra (Luigj Gurakuqi).

We think that the Albanian opposition was united because of Zogu and his view of the Islamic religion, temporarily eliminating the profound differences they had and will continue to have. So, the combined dissatisfaction of the Albanian Catholic and Orthodox population, made them unite, while never agreeing in advance for a unified program.
} 
In this period, Albania was not only not united in the political aspect, but also lacked most of the preliminary conditions that testify to the state unity of the country, such as the high degree of centralization, religious and linguistic unity, and so on. Meanwhile, the fierce political struggle developed in the 1920-1922 period between the highest state institutions (the government, the National Parliament, and the High Council), as well as outside them, damaging the country's normal political development, but failed to stop efforts for its stabilization. But if we highlight also its problems with its neighbors (Yugoslavia and Greece), emerge the difficulties faced in the above-mentioned years. It is worth mentioning that from January 1920 to December 1924 in Albania 13 governments have changed.

But despite the political chaos, as a result of the frequent change of governments and problems with neighbors, this period also marked the peak of the Albanian political life. This arose because political parties appeared, programs were announced, newspapers were published, and above all, a previously unheard political debate took place.

\section{Sources and Literature}

\section{Archival Sources, Unpublished Sources}

[1] AQSH, Fondi Personal Fan Noli, Fondi. 14. Dosja. 89. Programi i Kabinetit.

[2] AQSH. Fondi: Kongresi i Lushnjës, Dosja. 1, 1 janar 1920. Programi i Kongresit të Lushnjës.

[3] Statuti i Shoqnis "Bashkimi", (1924), Tiranë.

\section{Published Sources}

[1] Bisedimet e Këshillit Kombëtar. 15 nëntor 1920.

[2] Naska. Kaliopi, (2000), Këshilli Kombëtar 1920 (Parlamenti i parë shqiptar). Drejtoria e Përgjithshme e Arkivave, Turanë.

[3] Nuro. Kujtim \& Bata. Nezir, (1982), Hasan Prishtina (përbledhje dokumentesh), 1908-1934, Drejtoria e Përgjithshme e Arkivave, Tiranë.

\section{Literatura}

[1] Abdyli. Tahir, (2003), Hasan Prishtina në Lëvizjen Kombëtare e Demokratike Shqiptare 1908-1933, GME, Prishtinë.

[2] Arifi-Bakalli. Emine, (1982), Qeveria demokratike e Fan Nolit dhe qëndrimi i Mbretërisë SKS ndaj saj, "Gjurmime Albanologjike", Seria e shkencave historike, XI-1981, Instituti Albanologjik, Prishtinë.

[3] Arifi-Bakalli. Emine, (2015), Përballje historiografike, Instituti Albanologjik, Prishtinë.

[4] Augustin. Robert C. (2011), Fan Noli dhe një revolucion i ikur (Demokracia Shqiptare në vitet 1920-1924. Koha, Prishtinë.

[5] Bartl. Peter, (1999), Shqipëria Nga mesjeta deri sot. Drita, Prizren.

[6] Castellan. Georges, (1997), Historia e Ballkanit, (shekulli XIV-XX), Gutenberg, Prishtinë.

[7] Dervishi. Kastriot, (2006), Historia e Shtetit Shqiptar 1912-2005. Organizimi shtetëror, jeta politike, ngjarjet kryesore, të gjithë ligjvënësit, ministrat dhe kryetarët e shtetit shqiptar, Shtëpia Botuese 55, Tiranë.

[8] Drini. Skender, (1984), Bajram Curri, Shtëpia Botuese 8 Nentori, Prishtinë.

[9] Historia e Popullit Shqiptar III, (2007), Akademia e Shkencave e Shqipërisë, Toena, Tiranë.

[10] Jacques. Edëin, (1998), Shqiptarët. Historia e popullit shqiptar nga lashtësia deri në ditët e sotme, Kartë e Pendë \& Fondacioni Abraham Linkoln, Tiranë.

[11] Jasa. Mediha, (1958), Bajram Curri, Patrioti Revolucionar i Shpellës Dragobisë, Ministria e Arsimit dhe Kulturës, Seksioni për përhapjen e njohurive tekninoko-shkencore, Tiranë.

[12] Krasniqi. Afrim, (2006), Partitë politike në Shqipëri (1920-2006). Historia dhe tiparet e partive, parlamenteve dhe të zhvillimeve politike. Tiranë

[13] Luku. Esilda, [2015], Diplomacia evropiane ndaj Shqipërisë ndërmjet dy konferencave të paqes (1919-1946), Instituti Albanologjik, Prishtinë.

[14] Mema. Albana, (2014), Situata në Shqipëri pas krizës së rëndë politike të vitit 1921 dhe kryengritjes së marsit 1922. "Studime Historike", Nr. 3-4, Qendra e Studimeve Albanologjike-Instituti i Historisë, Tiranë.

[15] Puto. Arben, (2009), Shqipëria Politike 1912-1939, Toena, Tiranë.

[16] Rushiti. Liman, (2016), Lëvizja Kaçake në Kosovë (1918-1928), Instituti i Historisë, Prishtinë.

[17] Swire. Joseph, (2005), Shqipëria, Ngritja e një mbretërie, Dituria, Tiranë. 
[18] Selmani. Hysen, (2008), Nga notimet e Zogut I Mbretit të shqiptarëve. Tiranë.

[19] Shala. Xheladin, (2014), Hasan Prishtina vështrim i shkurtër atdhetarie, Instituti Albanologjik, Prishtinë.

[20] Vickers. Miranda, (2008), Shqiptarët një histori moderne. Bota Shqiptare, Tiranë.

[21] Vllamasi. Sejfi, (2000), Ballafaqime politike në Shqipëri 1897-1942 (Kujtime dhe vlerësime historike), përgatitja për botim Marenglen Verli, Neraida, Tiranë.

[22] Zavalani. Tajar, (1998), Histori e Shqipnis. PHONIX, Tiranë.

\section{Literatura e shfrytëzuar:}

[1] Arifi Bakalli. Emine, (2013), Çështje nga historia modern dhe bashkëkohore shqiptare. Instituti Albanologjik, Prishtinë.

[2] Çami. Muin, (1974), Lëvizja demokratike e revolucionare shqiptare në vitet 1921-1924, "Studime Historike", Akademia e Shkencave e RPSH-Instituti i Historisë, Tiranë.

[3] Culaj. Lush, (1997), Komiteti Mbrojtja Kombëtare e Kosovës 1918-1924, Instituti Albanologjik, Prishtinë.

[4] Culaj. Lush, (2004), Shqipëria dhe problemi kombëtar 1918 -1928, Instituti Albanologjik, Prishtinë.

[5] Fjalori Enciklopedik Shqiptar 3, (2009), Akademia e Shkencave e Shqipërisë.

[6] Jorgaqi. Nasho, (2005), Jeta e Fan S. Nolit, OMBRA GVG, Tiranë.

[7] Meta. Beqir. (2002), Federata Panshqiptare "Vatra", Globus, Tiranë.

[8] Palnikaj. Estela \& Palnikaj. Dritan, (2016), Fan Noli në Parlamentin Shqiptar dhe roli i tij si opozitar, Kumtesat nga konferenca vjetore e shkencës 'Java e Shkencës' 2015, Prishtinë.

[9] Shala. Xheladin, (2014), Hasan Prishtina vështrim i shkurtër atdhetarie, Instituti Albanologjik, Prishtinë.

[10] Shehu. Neil, (1977), Formimi i Federatës Atdheu dhe Programi i saj, në "Çështje të Lëvizjes Demokratike dhe Revolucionare Shqiptare në vitet 1921-1924", Tiranë.

[11] Shtylla. Zamir, (1986), Rreth krijimit dhe veprimtarisë së Komitetit Mbrojtja Kombëtare e Kosovës në vitet 19181920, "Studime Historike", nr.3, Instituti i Historisë, Tiranë.

[12] Shtylla. Zamir, (1986), Rreth krijimit dhe veprimtarisë së Komitetit Mbrojtja Kombëtare e Kosovës në vitet 19181920, "Studime Historike", nr.3, Tiranë.

[13] Spahiu. Avni, (2015), Vatra e shqiptarëve të Amerikës dhe Noli. Fan S. Noli-figurë emblematike për shqipen dhe shqiptarët, "Scupi", vëll.13, Instituti i Trashëgimisë Shpirtërore e Kulturore të Shqiptarëve, (Trubunë shkencore), Shkup.

[14] Ushtelica. Ilir, (1997), Diplomacia e mbretit Zogu I, Tiranë.

Printing press: Politika, 3 maj 1924. 